\title{
Woman as embodiment of nature: A cultural ecofeminist analysis of The Last Quarter of the Moon
}

\author{
Nazir Muhammad*1 | Lubna Hussain ${ }^{2}$ | Iqbal Khan Ahmadzai ${ }^{3}$
}

1. Department of English, Higher Education Department, Khyber Pakhtunkhwa, Pakistan.

2. Department of English, Government Post Graduate College, Mardan, Pakistan.

3. Department of English, Faculty of Humanities, Maryam University, Kabul, Afghanistan.

*Corresponding Author Email: nazirlec.gpgc@gmail.com

\begin{abstract}
The paper explores influences of postmodern technologies over the deeprooted ideological order of the ancient Chinese Evenki tribe in Chi Zijian's "The Last Quarter of the Moon". The technological advancement and subsequent cultural transformation resulted in a great imbalance in the ecology of rivers, mountains, and forests and the feminine gender was the recipient of most of the consequences and disparities because of the women's true spiritual socializing-relationship with nature. The divine embodied bond between women and nature was a source of inspiration and empowerment for the Evenki women. Modern way of life and lust for material progress blinded Evenki vision to the healing powers of nature once witnessed and utilized by their ancestors. The paper critiques the unsettling society of ancient deep-rooted spiritual order of Evanki based on their interdependent relations with spirits, the woman and mother nature. The study subscribes to the theoretical postulates of eco-cultural feminism as theorized by Merchant (2005) and Starhawk (1990). The relationship between woman and nature got destroyed when the world of Evenki shrunk under the spill of postmodern race and evaded by greed for money. The technological advancement and the resultant tempering in nature is a suppression for both women and nature.
\end{abstract}

Article History

Received:

April 9, 2021

Last Revised:

June 17, 2021

Accepted:

June 18, 2021

Published:

June 30, 2021

Keywords: woman exploitation, nature exploitation, spiritual relationship, spiritual interdependent relationship, post-modern technology, transformation of culture.

How to Cite: Muhammad, N., Hussain, L., \& Ahmadzai, I. K. (2021). Woman as embodiment of nature: A cultural ecofeminist analysis of The Last Quarter of the Moon. Liberal Arts and Social Sciences International Journal (LASSIJ), 5(1), 568-581. https://doi.org/10.47264/idea.lassij/5.1.37

Publisher's Note: IDEA PUBLISHERS (IDEA Journals Group) stands neutral with regard to the jurisdictional claims in the published maps and the institutional affiliations.

Copyright: () 2021 The Author(s), published by IDEA PUBLISHERS (IDEA Journals Group). This is an Open Access article published under the Creative Commons Attribution-NonCommercial 4.0 International License (http://creativecommons.org/licenses/by-nc/4.0/) 


\section{Introduction}

The progress, advancement, and evolution of world under the banner of modernism has brought with it manifold and undesirable ambiguities. The beliefs and principles of freedom and equality have been attended by new forms of oppression, persecution and exploitation. However, the idea of equality achieved the emergence of various emancipation movements. As globalization marched on the road to modernity, literature throughout the world also went through radical changes. The meeting point for this change was the colonizing process. The colonizing process, therefore, made it easier for various works of literature to cross the geographical borders and get acknowledged. This remarkable road has placed the words in such a pace that no borders may stop them now. In turn, these works have helped to promote cultural understanding of different nations and to analyse that how technology affects those cultures and nature. Chi Zijian's The Last Quarter of the Moon presents a good example of how the values present in Chinese culture apparently got transformed to material foundations under the aggression of postmodernism.

Ecofeminism theorizes an association of woman to nature and ecology. The theory of ecofeminism emerged with growing awareness of the relations between women and nature. The term, "ecofeminism," was coined by French writer Francoise d'Eaubonne in 1974 who compelled "women to lead an ecological revolution to save the planet" (Merchant, 2005, p. 184). This is because to demonstrate the potential of women to make significant contributions to an ecological revolution. The term was popularized through its use in protests against environmental destruction. This ecological revolt would involve new relations that will be based on gender. These relations would not only be between woman and man but also between humans and Nature. Charlene Spretnak says that Ecofeminism is the product of cultural feminism. The concept, which holds that the traces behind the authority of male over female is the key to grasp every expression of masculine culture with its hierarchical, aggressive diplomacy, bureaucratic nature, and capitalist forms.

Ecofeminists discusses two significant themes the acknowledgement of the dynamic link between social supremacy, subjugation, and feminism, and the notion of human and nature interdependence. Several feminists says that woman and nature have specific relation not because woman is oppressed but because woman and nature are both exploited by the man that's woman and nature have spiritual and integral relationship. The suppression of women and Mother Nature is obvious in the gendered language when men are describing Mother Nature and woman. Some discourses relate women especially to the nature because of their social role as a nurturer and caregiver. Ecofeminists illustrates that the association of woman with nature is because of the natural associative quality of caring the environment. Shiva (1988) says that this specific interconnection between woman and nature has been ignored. Shiva is of the view that women in subsistence economies, who produce wealth in partnership with nature, have been experts in their own right of holistic and ecological knowledge of nature's processes. She is against development based on Western patriarchal perceptions of development and progress. She adds that patriarchy has labelled women, nature, and other groups not growing the economy but cause unproductive progress.

Cultural ecofeminism is a reactionary response to the polarized view that woman and nature have been mutually linked, associated, and degraded in modern global culture. Cultural ecofeminists want to uplift and set women and nature free even through political actions. It is a vision in which nature is believed to be in great reverence as Mother-Mother Nature. It is a 
foundation that inspires as well as empowers activists of ecofeminism. In the structural framework of cultural ecofeminism, spirituality is held as the basis of both the individual and the social change.

Postmodernism has brought the world to the point where it challenges the ideological, social and historical structures. Zijian's The Last Quarter of the Moon displays the troubled world of the Evenki tribe under the spill of postmodern pace of global race in greed for money. This diminishing world of their tribe represents the unsettling of ancient deep-rooted ideological order that is based on the Spirits, the Woman and the Mother Nature-a source of inspiration and empowerment for them. The novel elucidates the spiritual bonded and embodied relationship between nature and women in terms of motherhood. This spiritual bond is collapsed through technology and modern civilization rules of development. Zijian highlights rituals, spirits and natural environment as a source of earthly life for woman in the novel.

In order to achieve objectives of the study and answers to the questions; firstly, the research article reviewed up to date literature on the area and novel to provide compact information on the field. Secondly, methodology stipulate step by step process that how have primary text been analysed through theoretical framework. The analysis of the textual references proves the researcher stance and conclusion summarises the main points of the research, recommendations and new area for further research.

\section{Literature review}

The novel has been discussed from various points of view. Hahn (2015) describes that the novel is about a lifespan, and existence of special attitude, as distant from ours as one can visualise and think. He is of the view that the people depicted in the novel are different in their source of revenue and livings. The Evanki people have a specific natural relationship with forests and mountains. They worship goddesses and spirits and these customs and traditions make them distinguish from other people of the world. It is a depiction of life entirely different from what English-readers might have come to expect of a Chinese novel. Hahn appreciates the narrative of the story that portrays situation bit by bit to attract readers and convey the message successfully with simplicity and empathy.

Henitiuk (2012) describes about the global worldview of the civilizations, culture and literatures. The writer is explaining the idea of the single text share as globally recommended idea for spreading the ideas. He is considering points about the Tawada view of putting literature in front of many different cultural interpreters. What are those ways to that piece of literature may be work or interact successfully in the global readers. The piece of literature gives the ideas of different cultures in the world and claims that literature should be written outside the nation. The piece of literature leaves its homeland and merges in the global world. However, neither the text leaves its homeland fully nor can it be incorporated in the broader world. Still literary translation is much valued work although there are different cultural languages involved in the writer culture and the translator or target language to which the text would be translated. The text reaches to the new audiences and readers. The newly literary piece is welcomed to the new reads.

Eisler (1990) is of the view that there should be a political global struggle for changing the concept of the world regarding nature and its interdependent status. The people should realize that we are partners i.e. nature and human beings are partners in the world. They could not live 
separately. Whatever the civilization and modern culture we have but we are to respect nature. There are ways if we try to live with peace with nature, the spirituality, science and technology and technology could live together. If we are to establish and promoting our new culture and traditions we are to run the intuition and reason parallel for building up harmony with environment. Cooperation is the main crux of the philosophy. We are to accept that spirituality is not only the domain of religion, we can have better spiritual relationship with our nature as our elders had once, were living happily with nature.

Kellner (1995) states that media cultural artefacts are not innocent. These artefacts constructs the idea of the readers, it spreads the newest prograde through these texts and effects the world view. The writer says that these cultural artefacts needs ideological criticism and one should include gender, sexuality, race and class. The critics should have through study of the resources media culture is using whether the media use images, figures, or myths. Although these could not be limited in certain words because they are using different tools and ways to attract readers. So to criticise a text we should have a multicultural knowledge and multi perspectival ideas for any texts and especially for media cultural studies. The deconstruction and posts structuralism idea should be applied to such studies that are multicultural. The class, gender and race and its relation with power domination and resistance. These are the important tools for any theoretical analyst to study multicultural text

Li-na (2007) describe the history of the Evanki tribe that live in china. They are inhibited in Xing'an'Lin and their living is based on the feeding of Reindeer. These people have special skills in taming the reindeers and consider their peaceful lives as combination of the nature and reindeers. They have developed a common wisdom with surrounding nature. They have the ideology of interdependence life with the environment. The special attachment with nature provide them the language of the nature and forests. The attachment is spiritual with Mother Nature. The Mother Nature in response cures them and feed them. This natural living of life in the forests Xing'an'Lin is proof a specific mutual relationship between humans and these forests. The modern man where person fear to lose the modern facilities, communication sources and medication, the Evanki tribe is living happily. Xie (2018) interprets the same history of the Evenki ethnic minority. The writers points out the similarity between Evanki in China regions and Siberia. They are officially recognized as people who use Reindeers for living life. Later on since 1949, there identity has been changed from category of "hunter" to that of "reindeer herder".

Nagle (2014) opines that world literature in the modern sense refers to the piece of literature that are translated into the Multilanguage. The point of view does not believe in world boundaries, rather they believe in the concept of global world. The literature spreads the ideas of multiculturalism, concepts and multi perspectives from multiple on an area of exploration. Although there are different concepts regarding translation of the literary piece that in the target language texts loses its power that is was originally contested. The text is always dependent on the translator. Some of the critics believes that every text in any culture is free of the actual context more or less every text has been influenced by modern social communication resources therefore World literature shows us how information is shared among many traditions and discover the new ideologies to the new readers and critics.

Falconer (2015) explores the relation in term of deepen roots in their habits of life and customs that how the Evenki survives famine, disease, war and reform, lethal snowstorms and accidental shootings but one thing they cannot endure is displacement. The detachment from 
nature is hazardous. Falconer is stressing the uncertain situation of the people that are emotionally attached with nature. The Evanki people could not live without the nature; mountains, hells, trees, animals, once their ancient sages had lived with nature. The Last Quarter of the Moon is titled in Chinese as The Right Bank of the Argun, a hint that the story is based on fact. Falconer is of the view that it is the story of almost every person and family who had been living on the bays of rivers and forests. The Evanki people believe that as a child entering the mountains to fetch firewood is not good and the spirits Bainacha and Oroqen would punish them. He is critically analysing the delicate nature and innocence of the people that worship nature and spirits.

Jiang (2020) describes that The Last Quarter of the Moon defines Reindeer ethos and the living conditions of the Ewenki people over a century. As an olden nomadic culture, the Ewenkis lived a life based on the native culture in the highest mountains and dense forests of the Greater Xing'an. Reindeer culture is a typical representative of these mountains. It reflects the daily production and life of the Ewenki in harmony with nature. Their daily life includes clothing, food, shelter and transportation; while spiritual life includes religious beliefs and art; and the theme of the work embodied by the reindeer. The novel is deep thinking on the integration of primitive ecological civilization and modern civilization.

Gillet (2014) opines that The Last Quarter of the Moon is a story of eternal nomadic life endangered by new technology and change. The strength of the novel is that it doesn't preach morality and the negatives or positives way of living. It is neither a narrow-minded adherence to nomadic life nor a tale getting benefits from modern people and technology. It is only a beautiful written story of the adversities where people endure the effect of new technology, and the last survivor speaks the tale. Alone, the 90-year-old woman, last chieftains of the Evenki reindeer herders anticipates her life, and the disappearing traditions of her people. Unfolding her childhood and the adult life as one of the nomadic reindeer herders of the Inner Mongolia, the chieftian depicts a brilliant portrait of the loveliness and the suffering that comes with a life so conditional on the land. What follows is a painful tale of the strength and endurance, shamanism and death, of heartache, grudges and bonding, and, finally, of the end of a traditional way of life.

Popesco (2014) states how a 90-year-old woman gazes back on a riotous past, administered by traditions, the commandments of nature and the willpower of the Spirits. The narrator is from a tribe, lives in forests through her memories we imagine the harsh condition of the Evanki tribe. They are surrounded by natural beauty and celebrate the life in lyrical prose. Moreover, Popesco adds that the children are mainly susceptible to the different dangers in different shapes because of the new modern cultures that disturbs their lives. Hahn (2014) looks at how Chi carries the reader from outside spectator to a place inside the head and spirit of the people. The readers feel themselves in the life, which shows the skill of the writer. The spirits and their relationship with women, the goddesses have been shown realistically. We as readers are influenced to accept the destructions of the modern technologies in shape of untimely deaths, disease other consequences.

Housham (2014) opines that the old woman refers back to a life full of hardships and tumultuous unwished changes, which becomes almost impossible living. But she is contented with a family life full of children and passionate relationships. She is happy with her life but suddenly everything changes with the military invasions and war with Japan and Russia. The Increase in military and industrial activity interrupts on the timeless world of the Evenki, and 
they are weaker to defend their cultures and lives. By the time the narrator's life has been brought more or less up to date, one senses that their culture, which was so enthrallingly evoked, is doomed. Mialaret (2014) beautifully shows that the novel never goes easily as beautiful poem about life, people, and nature. The Reindeer that was combination of Spirits, forests, traditions and cultures could not be the same if technology comes and the Evanki could not be as usual with in the interdependent relationships. The Reindeer and the people searches places for eating and drinking. They migrate from one place to another for their needs and it's a routine life, but they are all together and happy for them, therefore, reindeer and shamans are the real key-players.

Most of the reviewed articles are concerned with ecofeminism which shows woman and nature relationship. The ecofeminists discusses similarities between woman and nature in term of its caring others and biological statuses. However the article in hand is more deepen study of the area from a different perspective which is spiritual cultural ecofeminism from an antitechnology viewpoint where woman and nature are not only interdependent but spiritually linked and this spiritualism has been shattered by postmodern technology. Furthermore, the old culture and traditions are transforming to modern culture along with replacement of old beliefs, and conventions and the situation is more precarious for the modern world because the whole ecological system would be abolished and mankind would suffer the consequences. The literary piece strengthen the claim that the area should be analysed for the concept. Therefore, present study explores the novel with the lens of cultural ecofeminism in the vast picture of postmodernism. By socializing the relationship between woman and nature, this study exhibits the shrinking world of Evenki under the spill of postmodern race of global greed for money. The present study also represent the unsettling Evanki society of ancient inherent ideological order based on the Spirits and goddesses, the woman and the Mother Nature-a source of inspiration and empowerment for them.

\section{Theoretical framework}

Theoretical framework is based on Merchant's (2005). He is of the view that nature is spiritual and personal while biology of both the human and the Nature is same because both are reproductive. Focusing on the cultural ecofeminism, Merchant says that it (i.e. cultural ecofeminism) is against the new technological development. Therefore, cultural ecofeminism links woman and nature based on ancient rituals. Women considers nature, the moon, animals, sun and forests as goddess. The women worshiped nature and respect nature as mother and goddess as a universal religion. Nature is a source of motivation and empowerment. This is a special type of bond between the women and nature and caregivers. However, Merchant believes that science and technology are problematic, both put stress on domination. Another critic Starhawk (1990) focusses on the relation between nature and human being especially on women and nature. For her, spiritual ecofeminism is an earth-centred religion. Also, nature worship is a system of religion which is based on the veneration of natural phenomena. She believes in the religion that worshiping earth, nature, and fertility are various forms of goddess of a universal religion. For her, we as a community are interrelated with the earth. According to Rihanna (as cited in Mettetal \& Kappel, 2020), spiritual ecofeminism is not limited to only one religion rather it is extended to different values like kindness, sympathy and non-violence.

\section{Research methodology}

This research is qualitative in nature. The novel has been analysed critically through theory of 
ecofeminism, especially the cultural and social ecofeminism. Through close reading, the quotes have been selected from the novel for answering the research questions and strengthening the viewpoint of the researcher to find the underlying meaning. Secondly, the selected quotes are analysed through Merchant (2005) and Starhawk (1990) views of Eco cultural feminism and spiritual eco feminism to support the argument. The research paper investigates the transformation of culture from old rituals to the modern technological culture. Where, the natural spiritual relationship of human being is replaced by greed for money and capitalistic benefits at the cost of nature and women demolition. Moreover, for the identification, the eco cultural feminism the study also uses the model of thematic analysis presented by Braun and Clarke (2006). There are six phases, which are as follow:

- To read and re read the textual data critically and analytically, making notes of the data.

- Generating initial codes which are building blocks, related to the research questions and based on semantic or latent level of meaning, the deeper meaning of the data.

- Searching the themes/searching the themes, the data shifting from codes to themes in relation with research questions to generate themes rather than discovering themes.

- Reviewing the potential themes.

- Defining and naming themes.

- Producing the report.

\section{Discussion and findings}

This is the story of a time-tested relationship between an old woman and the nature. This story describes a relation based on the age and experience, both have encountered in ninety years. She is a "long- time confidant of the rain and snow". She is ninety years old but she proudly expresses her emotions by saying that the "rain and snow have weathered (her), and I too have weathered (them)" (Zijan, 2005, p. 9). This ninety years old lady begins her story by crossing a line between the friendship of humans to their own species and the one with the nature - the rain and the snow. She is not only a caretaker of her reindeer but she also shares the same feelings with them. Life in the Evenki tribe continues as it has been for the scores of years.

Nature has a positive impact on the human nature. The narrator describes herself to be the part of nature. She can't imagine living without accompanying nature, as she says, "I won't sleep in a room where I can't see the stars. All my life I have passed night in their company" (p. 9). The narrator enjoyed her life with a close connection to nature. She finds happiness with shining stars in the night. Her love for nature makes her life possible even in an extreme environment where rain and snowstorms make life miserable. She cannot sleep in a room where she cannot see the sky and stars. She utters her soul when she says, "I have always breathed the fresh air of mountain wilderness, and if I have to inhale the parts emitted by the cars in Busu, I'll suffocate" (p. 9). Her suffocation in the city is a symbol of her oneness with Mother Nature. Nature is her soul. She is unable to think of life without being in the company of Mother Nature. She does not like the city crowd where people are busy in their struggle for material gain. She expresses her dislike for dust and noise in the city, as "the city is full of people in motion, vehicles and dust, and it was really a bore" (p. 175). It shows her rejections of modern life, the life in cities that are full of heavy smoke and noise of vehicle. She feels suffocation in the city life because there is no fresh air like that of the mountains which she has been living since her childhood. Throughout the novel, the narrator expresses her spiritual attachment with nature. The nature is source of satisfaction for her. She feels easy with that old relation which 
has been a bond for life without disturbance. The life of city is really bored and restless for the people who lived their whole life in a peaceful environment of mountains.

\subsection{Nature and woman relationship}

The first relation of woman and nature shown in the novel is physical. It is a physical attachment between the two. With the passage of time, she understands the spirit of Mother Nature and gradually knows the secrets of nature. Most important, she becomes a part of the function of nature when human beings deal with nature. However, physical relation leads her to the spiritual relation. Nature therefore, becomes her favourite abode. She expresses her love for the spirit of nature when she says, "My body was bestowed by the Spirits, and I shall remain in the mountains to return it to the Spirits" (p. 10). They believe in the spirits that live not only in the forests but also in the far off mountains and trees. They celebrate their shamanistic relationship with nature by tending their reindeer. This makes life possible in such an extreme climate. They live, they love, they dance, they hunt, they share their jokes, but they do not hate their climate even in extreme conditions. They shift their camps in search of food and hunt, but they do not destroy nature. That is why the narrator addresses them when she speaks out her hear, "Then let the rain and the fire listen to my tale. For I know these foes, like human beings, have ears too" (p. 10).

The lady feels herself one with nature. Every one leaves but she still sits there, telling her lifelong story to the nature in the presence of nature. Though no one takes interest in her story now, still she tells it to the swishing of the rain and dancing of the flames. Their feasts are not alone. The feasts are sources of unity with nature. She understands the language of nature. For her, the language of nature is thoughtful as well as a source of eternal happiness. She knows how nature has similarities with the women in the surrounding. She detects that leaving nature will be the end of life for her. The villagers are impacted by the modern-day life, and they fall prey to mental illness and psychological evils. Still, she wants to tell the story of the spiritual relationship that exists between natural environment and human being, though no one listens. She is merged with the nature. Therefore, she understands nature and the environment as part of her physique. Their feasts are not alone. They celebrate their feasts with worshipping the spirits. It is their belief in the spirits that they worship these spirits like living beings. These feasts are part of the religious practices. They consider nature to be the part of a whole, the whole that leads to the god. The feasts are the contacts with the god that systematizes the life for them as:

Nidu the shaman said "there are two thunder spirits, one male and one female, who govern the weather in the mortal world. When it rained lightly, it must be the female thunder spirit appearing; when it rained heavily, it must be the male thunder spirit appearing" (p. 35).

These lines show the extent of their belief on the spirits. They believe that the whole forecast of weather is controlled by the spirits. It can be seen that the narrator effectively connects the smoothness of light rain with female spirit and the density of heavy rain with male spirit. There exists a stronger similarity of these images in the modern society where male is mostly found heavy in their behaviour as well as in the depiction of their social status. The female thunder is delicate, soft, and emotional like a woman. It is kind-hearted. Even in the nature, female thunder is depicted to be a source of consolation and prosperity. From this old lady, the softness and lightness of female thunder is intimation that females are constructive and positive. 
If they are sick, they migrate their reindeer for whom "the forest is their granary... they nibble lightly so that hardly a blade of grass is harmed and what should be green remains green" ( $p$. 39). The Evenki are skilled in the psychology of surrounding. They understand birds, rivers, rocks. Spiritually, a Shaman, their healer, guides them. Cinders of fire are kept alight for decades and are passed between generations. For them, the mountain forests are tranquil and shrouded in dark smokes. "If the Argun is the palm of a hand, then its tributaries are five open fingers. They extend in different directions, illuminating our lives like flashes of lighting" ( $p$. 39). They cannot live without the holy Argun. They are unable to leave as it serves as a centre for them. This spiritual bond that they have with nature-linking rivers with body and thunder storm-gives them inner strength. Their shirangju is an abode of immortals for them, a source of their spiritual strength.

Zijan put the character in a way that depicts the reality of the society. She portrays the real picture of a society where women have been living in an inferior status. These women have convinced themselves with surrounding. They have their own tributes to the nature which shows the instinctive natural elements. These natural instinctive elements are dances, sacrifices and sports, which shows the attachment of the women in the society, "Nihau began her dance. Typically, the spirit dance cannot be performed before the sky has turned dark, so it would be very difficult for the spirits to descend" (p. 120). This relationship is dependent upon the spirits and the goddess. They care for nature as nature has goddess for separate function in environment. This spiritual relationship of women and nature exists in shape of special religious relationship. The writer believes that it is a type of religious practice. For her, it is a source of the exact nature of woman, her true spiritual attachment with earth, nature, and fertility deity in the various forms of goddess. According to Riana (1990), spiritual ecofeminism is not limited to only one religion. Rather, it extends to different values like kindness, sympathy, and non-violence. For Starhawk (1990), the goddess should be physically present in some form so that her spirit could be felt in a sensible form. Nature for Evenki is but a physical form of goddesses.

The relation is more obvious in "I am mountains, you are water. Mountains create water, and water nourishes mountains. Where mountains and water meet, earth and sky are eternal" (p.127). The eternal relation between the nature and women is interdependent. If there is any disturbance in any part of the nature, it is likely to create commotion in the nature of woman. It seems a significant fact that woman would not tend to harm nature for the sake of her existence. If woman is water, it nourishes the mountain - a symbol of peace and prosperity. Women in society are affected by the surrounding development, which is mostly based on modern industrial revolution. They feel suffocation, psychological turbulences, and changes in their bodies. They are unable to imagine life without the winds. These winds are symbols of life for them, as the narrator says, "I just couldn't get used to the way everybody gathered round a table inside to eat, and at night they closed the door and windows so tight you couldn't even hear the wind blow" (p. 136). This is an obvious indication that they not only breathe the wind but also hear it. Wind as a part of nature exists as a living thing for them, a part of the spirits that nature has bestowed upon them. It is a source of life, which they can't breathe or hear when they are away from open air, inside the closed-door rooms and away from nature.

The old lady could not adjust herself in the environment. The people are happy and they adjust themselves with the new technological changes and variations in society. However, if she is not allowed the nature, it's not possible for her to live life. It is not about that she could not adjust the modern life but it's about the way they have been living and adjusting themselves in 
the natural worlds. They have an attachment with the mountains and their reindeer, a spiritual world, and a goddess-connection that they are unable to lose. The natural and artificial lives have difference in ways of dealing individual lives. The wind that they feel is fierce but it brings a unique happiness to them, as the lady expresses her emotional state, "I am grateful for the wind-sounds provided by Mother Nature that night, because when we began to voyage on our hidden river of life, enjoying our own unique happiness, a fierce wind began to blow outside our shirangju" (p. 147).

\subsection{Nature as healer and therapist}

Nature has always been a healer for those who believe in its spiritual influences. It has been a constant character in projecting and controlling emotions of women. Therefore, nature and women have an attachment in the manner they follow in worshipping the Mother Nature. Both can sense other, as the narrator believes when she says, "In my eyes, the wind and the flowing waters and the moonlight can hear what ails me" (p. 152). The illness they experience is not believed as an enemy. It is considered a part of nature, which appears in one or other forms through different spirits. They accept ill health as a part of spirits living in their heart, "Sickness is a secret flower hidden in one's chest" (p. 152). Also, if the spirits bring sickness, nature brings heal. Nature is their doctor, healer, and anti-depressor. The old lady describes her sentiments when she says, "All my life I have never been to a clinic to see a doctor. When I am depressed, I stand in the wind for a while, and it blows away the gloomy clouds in my heart" (p. 152). This is true not only for the physical illness but also for the mental agony they suffer in different circumstances. In all the difficulties, the nature in the shape of wind, water, sun, and moon is their solution: "When I am vexed, I go the riverside to listen to the waters flow, and they soon bring serenity to my heart. My doctors are the cool wind, flowing waters, sun, moon and stars" (p. 152).

Their belief in the spirit of nature is so deep-rooted that they perform rituals in its worship. The spirit robe of Shaman is generally a symbol of the spiritual leadership. When they ask for the rain, they perform a specific dance, "It was then that Nihau [the woman] donned her Spirit Robe, Spirit Headdress and Spirit Skirt, and drumstick in hand, and prepared to perform a Rain Dance for the last time" (p. 177). But the dance does not end here. It is their unique relationship with nature that they believe the Shamans call for. In her dance, she is immersed in her inner self in a constant relation with the spirits of rain, "Her back was bent, and her cheeks and eye sockets sunken" (p. 177). Her ritual items are not some exotic things. They are merely two "wooden woodpeckers as ritual items to pray for rain" (p. 177). These wooden woodpeckers are used as items through which rain is asked for. These wooden items are sub-merged in water and their beaks are headed towards the sky. This is where her dance begins.

\subsection{Trees and their spiritual worship}

I am an old tree that has lived through the wind and the rain without falling to the earth ...the children and grandchildren at my knees are branches on that tree. No matter how old I am, these branches will continue to flourish (p. 54). Their belief in themselves is stronger like things of nature. They are hopeful for the future as the narrator explores herself in the image of a tree when she compares herself to a tree that is firm and strong. It will continue to live. The lifethreatening snowstorm that they face is called white calamity where the women have to bear it, though they (i.e., women) "are made of water" (p. 71). They pass through generations but their relation with nature does not suffer. They see and treat the spirits of nature in every colour. 
Even the things they hunt are looked at as a gift and they mention the hunted things in their spiritual worships and dances, "The reindeer I painted was subdued" (p. 172). The narrator paints her life-long story of four generations in a way that represents four parts of the day-the dawn, the mid-day, the dusk, and the last quarter of the moon. Her paintings like the dawn begin vigorously as a child; they turn into the heat of the mid-day as a young and responsible lady; and they reach the dim light of the dusk in her old age. The sketches that she draws on the rocks of the Argun in bright, perky and lively colours turn dim, passive and submissive. Language of the Evenki encompasses not only their own Evenki but also that of Hans, Russians and the Japanese. Still, their own love for their spirit world does not hurt their belief.

\subsection{Impact of science and technology on Nature}

Greed for money makes them lose all they have - their values, spirit and love of nature: "As long as people aren't greedy for money, there won't be any disaster" (p. 27). However, as time passes by, they understand to deal with the clever Russians, followed by the silent and distant Japanese who force the male hunters and the Han Chinese to serve in the Manchukuo Army. The intensive tree felling threatens the survival of their reindeer. However, over the years, not only their reindeer leave but also their shamans. They give sacrifices for their people. Nonetheless, as a result of the modern capitalist cycles, they cannot see their children to suffer. Therefore, Nihau leaves with sacrificing her life for the goodwill of her tribe, her people. She dances for an hour, making the dark clouds to appear and shroud the sky. She starts swaying at the bank of the Argun when "thunder rumbled and a bolt of lightning lit up the sky, and rain poured down. In the middle of the downpour, Nihau intoned her final Spirit Song, but collapsed before she could finish" (p. 178).

The Mother Nature, the Spirits of the trees, and the shamanism interlocked in these Spirits are lost in the wake on progress and in the name of modern technology. Ecology of the Argun loses its hands and legs, the trees and herds of animals. The nomadic life of Evenki is pushed to a corner and the centuries old ways of life are crushed under the feet of technological war and the lust of money. "It feels as if the pale-white crescent has fallen to the ground. I'm crying, because I can no longer distinguish between heaven and earth" (p. 184). The last quarter of the moon stitches the sky and earth one for them as they have lost the only world they knew, a world of spirits and nature. "Whatever you love, that's what you end up losing. On the contrary, it's what you don't love that stays by your side forever" (p. 92). They love their spirit world, but they are unable to continue living there. They want to stay, but their "blood relations depart one after another like the stars at dawn" (p. 102). Finally, the Communists cage the nomadic tribe permanently. At last, they forget the sky in which they once soared. These things cannot be recovered once lost. They lose their livelihood, their passion for life, their cultural values and the world they actually know. The last quarter of the moon stitches the sky and earth one for them as they have lost the only world they knew, a world of spirits and nature.

\section{Conclusion}

The flow of materialistic improvements under the self-indulgence of postmodernism has made human beings helpless to follow the steps that lead to the relevant loss of their culture and ethics in morality. Zijian in her novel The Last Quarter of the Moon successfully paints the century-long tale in Eco feministic tone. She tries to socialize the relationship between woman and Nature through the world of Spirits. Her world revolves around the worship, the reindeer, the shamans, the spirit dance, the river and the moon. All of these are embraced by the Nature 
as Mother Spirit - a source of inspiration and empowerment for them. Cultural Ecofeminists supports the argument that modern science and technology have treated woman and nature badly. The woman and nature have a compulsory divine reciprocal bond. This bond between woman and nature is based on the revival of ancient rituals centred on goddess-worship. This is why nature is regarded as mother and goddess. However, modern day science and technology made this divine relationship worse and women lost her vital part (nature) of living. This is shown through the author's tale of her ninety years journey from the world of nature to the dark sky of materialistic expansions.

Zijian focuses on cultural ecofeminism from an anti-technology perspective and explores the vast picture of postmodernism. She emphasises the consequences of the Chinese culture, which has been transformed to material basis under the assault of postmodernism. Consequently, this transformation destroyed the ecology of rivers and mountain forests. The study exhibits the shrinking world of Evenki under the spill of postmodernism. Greed for money makes them lose all they have - their values, spirits, and love of nature. The last quarter of the moon stitches the sky and earth as an embodiment that can't be separated. Women lost the only world they knew, a world of spirits and nature. They lose their passion for life. Their children no longer know the spirits. They do not want to live in the mountains as the attraction of modern life and lust for material progress blind their vision to the healings of nature once lived by their ancestors. The writer emphasizes rituals, spirits and natural environment as a source of earthly life for woman because nature. Nature is believed to be in great reverence as mother, i.e. Mother Nature as a source of encouragement, motivation and empowerment. Zijian clearly points out the idea that woman and nature have distinct mystical bond, the science and technology disturb nature, which is directly proportional to the disturbance of woman. She thinks that both woman and nature have been suppressed and manipulated. The writer blames the technology and modern day science for the disturbance of natural environment and woman, their innocence, their delicacy, and their relation with spirits which must not have been disturbed because their happiness lie within these things, not elsewhere.

\section{Implication of the study}

The research analysis implies that environmental changes and its effects on the world. The world will afford the consequences of ecological disorder in shape of flood, earthquake and different diseases. The study is the awareness about the modern day technology and its brutal impact on Mother Nature. It is obvious that the environment and its spiritual relation with women has been given importance in the modern age. Still, it needs a more focused view in the future. The study is an effort to pinpoint the interdependent relationship of human with ecological system. Thus, the novel stands out as a unique contribution to the body of fictional works on spiritual ecocultural feminism. The novel as it not only depicts spiritualism and feminism but also, suggests how to overcome the problem and humanise relations with Mother Nature. Literature is better tool to identify and edify such problems and find out the solution.

The genera is more important than other research genres because it shows unique relation of woman and nature. It emphasis the feelings and emotions of woman with nature and describes detachment of woman from nature is detrimental to woman and to society in journal. The woman and nature have been dominated and suppressed. The study suggest that scientific development should not at the cost of ecological system. The theoretical framework and the methodology may be useful for the future research. 


\section{Suggestions for future research}

The ecofeminist analysis of The Last Quarter of the Moon gives clues to the future research. The effects of colonization and political approaches of different nations over Evenki tribe, that how the foreigners have exploited the cultural values and most importantly replace their old with new culture which has a dominant impact on the society and the more specifically on woman, effects of Post-Modern technologies on the environment and local culture, lifestyle and their beliefs about their own values. The second research area is the psychoanalysis of the main character, her desires for life and living as family together defending her culture and individual personality through defence mechanism. The comparative study of different characters will make the research more fruitful and generalized.

\section{References}

Braun, V., \& Clarke, V. (2012). Thematic analysis. In H. Cooper, P. M. Camic, D. L. Long, A. T. Panter, D. Rindskopf, \& K. J. Sher (Eds.), APA handbook of research methods in psychology, Vol. 2. Research designs: Quantitative, qualitative, neuropsychological, and biological (pp. 57-71). American Psychological Association. https://doi.org/10.1037/13620-004

Eisler, R. (1990). The Gaia tradition and the partnership future: An ecofeminist manifesto. Reweaving the world: The emergence of ecofeminism, 23-34.

Falconer, A. (2015). Evanki Life and culture. Facts and Details. https://factsanddetails.com/china/cat5/sub88/entry-4361.html

Gillet, K. (2014). Review of book The Last Quarter of The Moon, by Chi Zijian. https://www.scmp.com/lifestyle/books/article/1156175/book-review-last-quarter$\underline{\text { moon-chi-zijian }}$

Hahn, D. (2013) Review of book The Last Quarter of the Moon, by Chi Zijian. https://www.independent.co.uk/arts-entertainment/books/reviews/last-quartermoon-chi-zijian-trs-bruce-humes-harvill-secker-ps14-99-8478237.html

Henitiuk, V. (2012). The single, shared text? Translation and world literature. World Literature Today, 86(1), 30-34. https://doi.org/10.7588/worllitetoda.86.1.0030

Housham, J. (2014). The Last Quarter of the Moon, by Chi Zijian. http://www.newsmulti.com/books/2014/jan/10/the-last-quarter-of-the-moon-chizijian-review

Jiang, Y. (2020). A study of the English version of the last quarter of the moon from the perspective of ecotranslatology. International Journal of Applied Linguistics and Translation, 6(1), 20-23. https://pdfs.semanticscholar.org/ba14/33632e6695e5d28a7f49120d0b7294aa4fa2.pd f

Kellner, D. (1995). Media culture: Cultural studies, identity, and politics between the modern and the postmodern. Routledge.

Li-na, K. A. (2007). On the reindeer culture of the reindeer ewenkis. Heilongjiang Nationalities Series, $\quad 2, \quad 174-178 . \quad$ https://en.cnki.com.cn/Article_en/CJFDTotalHLMZ200702031.htm

Merchant, C. (2005). Radical ecology: The search for a livable world. Routledge.

Mialaret, B. (2014). The death of shamans, the twilight of evenki. http://mychinesebooks.com/author/bmialaret/ n.d. (2014) 
Mettetal, K., \& Kappel, C. (2020). Unstoppable and Devastating: Black female subjectivity, the environment and the Niger delta women's movement in The Naked Option: A last resort. Thesis for Bachelor of Science Journalism, Department of Interdisciplinary Studies at Emerson College.

Nagle, S. (2014). Theories in the context of globalization. www.publish.illinois.edu:https://publish.illinois.edu/globalcurrents/2014/12/03/worl d-literature-theories-in-the-context-of-globalization/

Popesco, L. (2013, Feburary 01). Enter another world with this magical novel of nomadic life as the time of the shaman ends. https://www.independent.co.uk/artsentertainment/books/reviews/the-last-quarter-of-the-moon-by-chi-zijian-transbruce-humes-8475333.html

Shiva, V. (1988). Staying alive: Women, ecology and development. Zed Books.

Starhawk. (1990). Power, authority, and mystery: Ecofeminism and earth-based spirituality. Reweaving the world: The emergence of ecofeminism (pp. 73-86). Sierra Club.

Xie, Y. (2018). From hunters to herders. Reflections on the "Ecological Migration" of the Chinese Evenki reindeer herders. Études mongoles et sibériennes, centrasiatiques et tibétaines, 49, 1-18. https://doi.org/10.4000/emscat.3414

Zijian, C. (2014). The Last Quarter of The Moon (B. Humes, Trans.). Harvill Secker. 